\title{
C-peptide: a redundant relative of insulin?
}

\author{
L. Luzi • G. Zerbini • A. Caumo
}

Received: 19 June 2006 / Accepted: 24 October 2006 / Published online: 16 January 2007

(C) Springer-Verlag 2007

Keywords C-peptide - Diabetic complications .

Type 1 diabetes

Historically, focus on C-peptide has been relegated to the exploitation of its peculiar pharmacokinetics (i.e. distribution and elimination) to derive accurate assessment of beta cell secretion, whereas, more recently, greater interest has been placed on its pharmacodynamics (i.e. the biological actions it exerts). In the present paper we will address the latter subject, but to put things in perspective - and because it is well known that kinetics and the time course of dynamics are intimately linked - we will begin with a brief overview of the kinetic properties of C-peptide.

C-peptide is stored together with insulin in the mature granules within the beta cell. It is secreted intraportally with insulin, on an equimolar basis, and shows the characteristic biphasic shape in response to i.v. challenges [1,2]. Whereas newly secreted insulin undergoes a large $(\sim 50 \%)$ hepatic extraction [3], the rate of which probably varies, all of the released C-peptide reaches the peripheral circulation without appreciable extraction by the liver. For this reason, C-peptide has proven to be a fundamental tool for accurate quantification of beta cell secretion. In fact, with the aid of kinetic modelling and deconvolution (the so-called EatonPolonsky approach $[4,5])$, C-peptide levels can be used to provide a reliable measure of the insulin secretory rate. To estimate C-peptide secretion by deconvolution, knowledge

L. Luzi $(\bowtie) \cdot$ G. Zerbini $\cdot$ A. Caumo

Section of Nutrition and Metabolism,

San Raffaele Scientific Institute,

20132 Milan, Italy

e-mail: luzi.livio@hsr.it of C-peptide kinetics is required. C-peptide kinetics are usually determined by analysing the C-peptide decay curve following a bolus injection of biosynthetic C-peptide. Polonsky described the kinetics of peripherally administered biosynthetic human C-peptide in terms of a linear, two-compartment model. The half-life of C-peptide has been shown to be relatively slow (approximately $35 \mathrm{~min}$ ), and glomerular filtration is the major route of its removal. The slow metabolism of C-peptide is consistent with the hypothesis that $\mathrm{C}$-peptide diffuses into the extracellular space, but is not integrated into cell membranes. In contrast, insulin is rapidly removed from the circulation (half-life approximately $5 \mathrm{~min}$ ) via insulin receptor-mediated uptake followed by lysosomal degradation.

In terms of its biological action, C-peptide has been long believed to be biologically inert, a sort of useless byproduct of insulin. In recent years, several intracellular effects of C-peptide have been described in vitro, and some in vivo studies have shown that C-peptide has an effect on clinical manifestations of diabetes complications (mainly in the short term). Such biological effects have been reviewed in the companion paper by Wahren et al. [6]. The key point of our argument is not whether C-peptide does or does not have a biological effect (this has been already proven beyond any reasonable doubt), but whether such a biological effect is actually relevant and can be profitably exploited to improve the health of diabetic patients by fending off the complications associated with diabetes. The crucial question is: Are the in vitro and in vivo data sufficient to consider C-peptide an endogenous molecule with a distinct physiology that makes it a suitable addition to the arsenal of therapeutic agents available to the clinician? In our opinion, this is not the case. We believe that C-peptide is neither the 'shavings of the carpenter's 
bench,' as previously believed, nor the upcoming 'magic bullet' of diabetes therapy. We offer three arguments to support this: (1) the lack of a specific receptor; (2) the lack of an effect in type 2 diabetes (excess of C-peptide and insulin); and (3) the lack of conclusive clinical studies.

\section{C-peptide receptor}

To classify C-peptide as an independent hormone, it would be necessary to identify its specific receptor. A few years ago, C-peptide was demonstrated to operate through the activation of $G$ proteins, and its receptor was therefore hypothesised to be a G-coupled receptor [7, 8]. Even though subsequent studies have confirmed that C-peptide acts through the activation of $\mathrm{G}$ proteins [7,9], the C-peptide-specific G-coupled receptor has not yet been localised. To increase the uncertainty in this field, independent investigators have shown that C-peptide has an insulinomimetic effect and that its action would be mediated through the modulation of the (tyrosine kinasecoupled) receptor of insulin [10]. It is obviously essential to clarify whether C-peptide is capable of simultaneously activating G-coupled and tyrosine-coupled receptors in order to understand its mechanisms of action. We present here some new preliminary results concerning the search for the C-peptide receptor through two independent approaches: (1) the screening of a cDNA expression library; and (2) the co-immunoprecipitation technique.

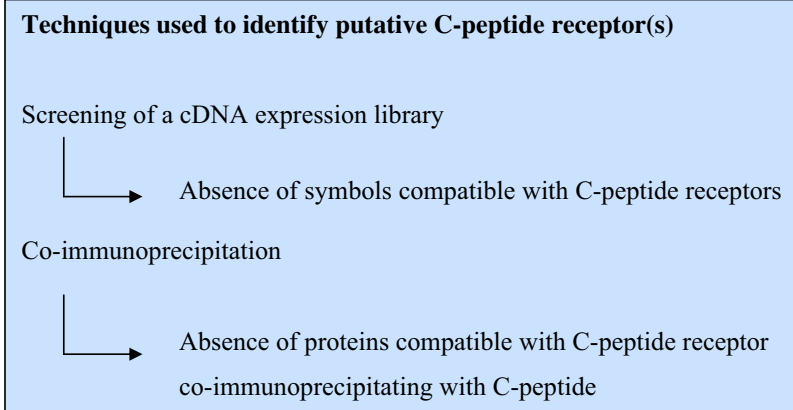

Screening of a cDNA expression library A human lung fibroblast lambda phage cDNA expression Library (Cat. no. 937212; Stratagene, Cedar Creek, TX, USA) was used for the study. Titration of the library was performed to evaluate stock efficiency, possible infection and percentage of recombinants. Blue/white colony screening of X-gal/IPTG plates was used to identify insert-containing phage.

To establish a permanent supply, the library was amplified by plating at high density using standard procedures. Plaques were then plated $(50,000$ per plate) and allowed to become visible. At this point, a nitrocellulose filter containing
$10 \mathrm{mmol} / \mathrm{l}$ IPTG was placed on top of the plates, which were then incubated at $37^{\circ} \mathrm{C}$ for a further $3 \mathrm{~h}$.

Filters were then removed and washed with Trisbuffered saline (TBS)-Tween $20(0.05 \%)$. Filters were then saturated with TBS-BSA $1 \%$ and incubated for $2 \mathrm{~h}$ at room temperature with TBS-BSA $1 \%$ containing $10 \mathrm{nmol} / 1$ N-terminal biotinylated C-peptide (Primm, Milan, Italy). Filters were washed once more and incubated for $2 \mathrm{~h}$ at room temperature with TBS-BSA 1\%, 1:5,000 Streptavidin-horseradish peroxidase conjugate (Amersham, Piscataway, NJ, USA). At the end of the procedure, chemiluminescence was evaluated using a chemiluminescence system and SuperSignal West Pico Chemiluminescent Substrate (Pierce, Rockford, IL, USA).

After double-screening, no positive signal was detected, suggesting that the screening of a cDNA expression library, at least as we performed it, did not permit the identification of C-peptide-specific receptors. Whether other kinds of approaches (such as biotinylation at a different position) would prove successful remains to be determined by further studies.

Co-immunoprecipitation Proteins were extracted from a culture of human fibroblasts using an homogenisation buffer containing $30 \mathrm{mmol} / \mathrm{l}$ Tris- $\mathrm{HCl}, \mathrm{pH} 7.5,10 \mathrm{mmol} / \mathrm{l}$ EGTA, $5 \mathrm{mmol} / \mathrm{l}$ EDTA, $250 \mathrm{mmol} / 1$ sucrose, $1 \%$ Triton $\mathrm{X}-100,1 \mathrm{mmol} / \mathrm{l}$ sodium fluoride, $5 \mu \mathrm{g} / \mathrm{ml}$ leupeptin, $1 \mathrm{mmol} / \mathrm{l}$ phenylmethylsulfonylfluoride (PMSF), $15 \mu \mathrm{g} / \mathrm{ml}$ aprotinin, $1 \mathrm{mmol} / \mathrm{l}$ sodium orthovanadate, $1 \mathrm{nmol} / 1$ C-peptide.

Protein A sepharose $(100 \mu \mathrm{l}, 50 \%$ homogenisation buffer) and $50 \mu \mathrm{l}$ antibody anti-human C-peptide (Abcam, Cambridge, UK) were added to $500 \mu \mathrm{g}$ of protein. After $2 \mathrm{~h}$ at $4{ }^{\circ} \mathrm{C}$, the sample was centrifuged at $500 \mathrm{~g}$ for $10 \mathrm{~min}$. Immuno- and co-immunoprecipitated proteins were then diluted in the same buffer as described above. Immunoprecipitated proteins were then separated by SDS-PAGE on a $12.5 \%$ gel. The resulting protein bands were then analysed by the MALDI-TOF technique.

Using this technique, the immunoprecipitated proteins consisted only of C-peptide and the immunoglobulin heavy chain characteristic of the antibody used for this test. Further studies are necessary to clarify whether, by modifying and improving the technical approach, it will be possible to detect some more co-immunoprecipitates possibly related to a C-peptide receptor.

\section{C-peptide and type 2 diabetes}

A major argument against the protective in vivo effect of C-peptide is that patients affected by type 2 diabetes develop complications at a rate not dissimilar from patients 
affected by type 1 diabetes. If C-peptide were necessary to avoid the development of diabetic complications, it would indeed be expected that patients affected by type 2 diabetes, whose C-peptide levels are generally higher than those observed in non-diabetic individuals, would also be relatively free from these complications.

If the actions of C-peptide were mediated by the insulin receptor, this phenomenon could be explained by a simultaneous resistance to both insulin and C-peptide. Conversely, if an independent G-protein-coupled receptor is the link between C-peptide and its actions, this phenomenon would appear more difficult to justify.

\section{C-peptide clinical studies}

Another important issue surrounding C-peptide is that, with the exception of indirect studies based on pancreas or islet transplants [11-13], there are presently no clinical studies lasting more than a few months that evaluated longitudinally the effect of C-peptide on the development/progression of diabetic complications in man [14]. Monitoring the effectiveness of C-peptide in the prevention of diabetic complications in longer, large-scale studies ought to be a simple enough task since C-peptide is certainly costeffective and could easily be added to the conventional insulin therapy. Such studies would also permit a thorough evaluation of the safety of the long-term administration of C-peptide, which is presently unknown. The safety issue needs to be addressed since recent studies have demonstrated that increased levels of C-peptide are associated with an increased risk of different types of cancer [15-18]. Although it is reasonable to postulate that increased levels of C-peptide simply reflect the concomitant presence of high insulin levels and insulin resistance, the possibility that C-peptide - together with its beneficial effects - may also have some undesired side effects, especially when given exogenously over long periods of time, cannot be ruled out at present. As time goes by, the lack of conclusive evidence on the clinical success of C-peptide and its long-term safety is disconcerting. Will C-peptide fulfil its promise or not?

In conclusion, we sincerely hope that John Wahren et al. are right and that $\mathrm{C}$-peptide can rapidly become the next breakthrough against diabetic complications. Until that day, a degree of scepticism towards the hype surrounding C-peptide is needed to help to focus research efforts on experiments that will provide the scientific community with conclusive answers.

Acknowledgements This study was supported by grants by the Italian Minister of Health (RF98.49, RF99.55, RF01.1831, First 2003).

Duality of interest The authors declare that they have no duality of interest.

\section{References}

1. Luzi L, DeFronzo RA (1989) Effect of loss of first-phase insulin secretion on hepatic glucose production and tissue glucose disposal in humans. Am J Physiol 257:E241-E246

2. Caumo A, Luzi L (2004) First-phase insulin secretion: does it exist in real life? Considerations on shape and function. Am J Physiol Endocrinol Metab 287:E371-E385

3. Ferrannini E, Cobelli C (1987) The kinetics of insulin in man, II. Role of the liver. Diabet Metab Rev 3:365-397

4. Eaton RP, Allen RC, Schade DS, Erickson KM, Standefer J (1980) Prehepatic insulin production in man: kinetic analysis using peripheral connecting peptide behavior. J Clin Endocrinol Metab 51:520-528

5. Polonsky KS, Rubenstein AH (1986) Current approaches to measurement of insulin secretion. Diabet Metab Rev 2:315329

6. Wahren J, Ekberg K, Jörnvall H (2007) C-peptide is a bioactive peptide. Diabetologia DOI 10.1007/s00125-006-0559-y

7. Al-Rasheed NM, Willars GB, Brunskill NJ (2006) C-peptide signals via $\mathrm{G} \alpha \mathrm{i}$ to protect against TNF- $\alpha$-mediated apoptosis of opossum kidney proximal tubular cells. J Am Soc Nephrol 17:986-995

8. Rigler R, Pramanik A, Jonasson P et al (1999) Specific binding of proinsulin C-peptide to human cell membranes. Proc Natl Acad Sci USA 96:13318-13323

9. Maestroni A, Ruggieri D, Dell'Antonio G, Luzi L, Zerbini G (2005) C-peptide increases the expression of vasopressin-activated calcium-mobilizing receptor gene through a $\mathrm{G}$ protein-dependent pathway. Eur J Endocrinol 152:135-141

10. Grunberger G, Qiang X, Li Z et al (2001) Molecular basis for the insulinomimetic effects of C-peptide. Diabetologia 44:12471257

11. Luzi L (1998) Pancreas transplantation and diabetic complications. N Engl J Med 339:115-117

12. Fiorina P, Folli F, Zerbini G et al (2003) Islet transplantation is associated with improvement of renal function among uremic patients with type I diabetes mellitus and kidney transplants. J Am Soc Nephrol 14:2150-2158

13. Shapiro AM (2003) Islet transplants and impact on secondary diabetic complications: does C-peptide protect the kidney? J Am Soc Nephrol 14:2214-2216

14. Johansson BL, Borg K, Fernqvist-Forbes E, Kernell A, Odergren T, Wahren J (2000) Beneficial effects of C-peptide on incipient nephropathy and neuropathy in patients with type 1 diabetes mellitus. Diabet Med 17:181-189

15. Bezemer ID, Rinaldi S, Dossus L et al (2005) C-peptide, IGF-I, sex-steroid hormones and adiposity: a cross-sectional study in healthy women within the European Prospective Investigation into Cancer and Nutrition (EPIC). Cancer Causes Control $16: 561-572$

16. Falk RT, Brinton LA, Madigan MP et al (2006) Interrelationships between serum leptin, IGF-1, IGFBP3, C-peptide and prolactin and breast cancer risk in young women. Breast Cancer Res Treat 98:157-165

17. Verheus M, Peeters PH, Rinaldi S et al (2006) Serum C-peptide levels and breast cancer risk: results from the European Prospective Investigation into Cancer and Nutrition (EPIC). Int $\mathrm{J}$ Cancer 119:659-667

18. Wei EK, Ma J, Pollak MN et al (2006) C-peptide, insulin-like growth factor binding protein-1, glycosylated hemoglobin, and the risk of distal colorectal adenoma in women. Cancer Epidemiol Biomark Prev 15:750-755 